7. Reprod. Fert. (1968) 17, 403-406

\title{
PROTEIN AND IMMUNOGLOBULIN CONTENT OF RETE TESTIS FLUID OF RAMS
}

\author{
M. H. JOHNSON AND B. P. SETGHELL* \\ Department of Physiology, Cambridge, and \\ A.R.C. Institute of Animal Physiology, Babraham, Cambridge \\ (Received 18th fune 1968)
}

There is little information on the accessibility of the seminiferous tubule to serum proteins and especially to the glycoprotein hormones or to immunoglobulins. The secretions of ram seminiferous tubules may be collected from the rete testis by inserting a cannula via the vasa efferentia (Voglmayr, Scott, Setchell \& Waites, 1967), and this paper reports the results of an analysis of these secretions for protein and immunoglobulin.

TABLE 1

PROTEIN AND IMMUNOGLOBULIN CONCENTRATION OF RAM SERUM, RETE TESTIS FLUIDS AND SEMINAL PLASMA

\begin{tabular}{|c|c|c|}
\hline Sample & $\begin{array}{l}\text { Protein concentration } \\
\text { (Biuret) } m g / m l \pm S . E \text {. }\end{array}$ & $\begin{array}{c}\text { Immunoglobulin } \\
\text { concentration } \\
\text { (radial immuno- } \\
\text { diffusion) } \\
(\mathrm{mg} / \mathrm{ml} \pm S . E .)\end{array}$ \\
\hline $\begin{array}{l}\text { Rete testis fluid from } \\
\text { rams with daily sperma- } \\
\text { tozoal production } \\
<0.5 \times 10^{9}\end{array}$ & $1 \cdot 10 \pm 0.26$ & \\
\hline $\begin{array}{l}\text { Rete testis fluid from } \\
\text { rams with daily sperma- } \\
\text { tozoal production } \\
>3 \times 10^{9}\end{array}$ & $1.02 \pm 0.32$ & $0.04 \pm 0.01$ \\
\hline Ram serum* & $89.00 \pm 0.75$ & $19.28 \pm 0.15 \dagger$ \\
\hline Ram seminal plasma & N.D. & $0.57 \pm 0.04$ \\
\hline
\end{tabular}

* The protein concentration of ram testicular lymph is 40 to 60 $\mathrm{mg} / \mathrm{ml}$ (Cowie, Lascelles \& Wallace, 1964).

† Confirmed by analytical centrifugation and cellulose acetate electrophoresis.

The Biuret reaction was used to determine the total protein concentration of rete testis fluid collected at different times of the year from rams showing wide seasonal variation in spermatogenesis. The values for rams showing active spermatogenesis were not different from those with poor spermatogenesis (Table 1). The protein content was much lower than that of testicular lymph,

* Present address: Ian Clunies Ross Animal Research Laboratory, G.S.I.R.O. Division of Animal Physiology, Prospect, N.S.W., Australia. 
presumably due to a barrier to protein between the interstitial tissue and the lumen of the seminiferous tubule. Such a barrier to various substances has been suggested previously (Setchell, 1967; Kormano, 1967), but Mancini, Vilar, Alvarez \& Sieguer (1965) have suggested that dye-labelled albumin, but not $\gamma$-globulin, could enter the seminiferous tubule of the rat.

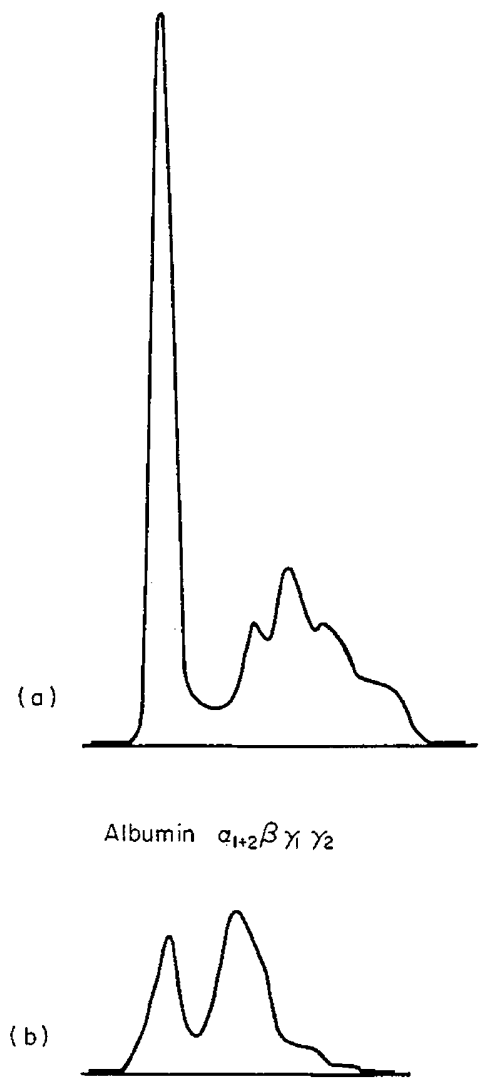

TExr-Fig. 1. Analysis of (a) ram serum and (b) concentrated ram rete testis fluid, by Phoroslide electrophoresis.

The rete testis fluid of some of the rams was concentrated between thirty-and seventy-fold by ultrafiltration, and the concentrate examined by cellulose acetate electrophoresis (Phoroslide, Millipore Inc.) and by immunoelectrophoresis. A typical cellulose acetate trace is shown in Text-fig. 1. A little albumin is present, plus traces of other serum proteins. A peak between $\alpha_{1}$ and $\alpha_{2}$ proteins is at least partially specific to rete testis fluid. Immunoelectrophoretic patterns using rabbit antisera to ram serum are shown in Plate 1, Figs. a to d. Many serum proteins can be identified in testicular fluid, including $\beta_{1 \mathrm{C}}$ (the $\mathrm{G}^{\prime}{ }_{3}$ component of complement) and $\mathrm{IgG}_{1}, \mathrm{IgG}_{2}$ and IgM. These last three all 
PLATE 1

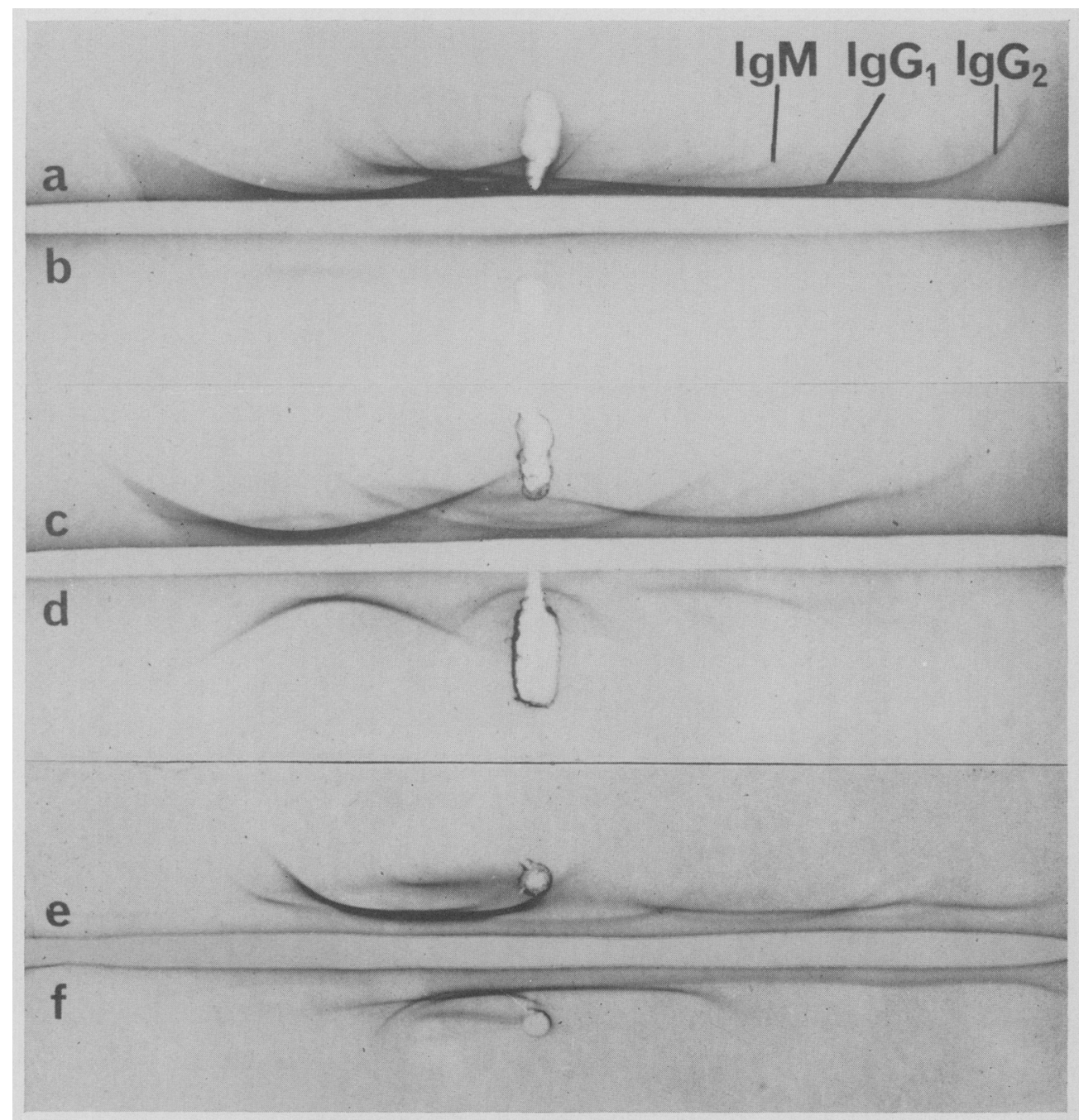

Immunoelectrophoretic analysis, using antisera to ram serum, of (a) ram serum, (b) normal ram rete testis fluid, (c) ram rete testis fluid concentrated $50 x$, and (d) normal ram seminal plasma; and of (e) ram serum and (f) concentrated ram rete testis fluid, using an antiserum against ram rete testis fluid. 
possess antibody activity and, in the guinea-pig, complement-fixing $\operatorname{IgG}_{2}$ antibodies appear to cause immunological aspermatogenesis and PCA $\left(\operatorname{IgG}_{1}\right)$ antibodies protect against damage (Chutna \& Rychlikova, 1964). Prolonged immunization of rabbits with testicular fluid did not reveal any antigens specific to testicular fluid ( $\mathrm{Pl}$. 1, Figs. e and f), as shown by complete absorption of antisera with ram serum or by cross-reaction of ram sera with testicular fluid proteins using the technique of Wadsworth \& Hanson (1960). The strong $\alpha$-protein line in rete t.stis fluid (PI. 1, Fig. e) cross-reacted with the $\alpha_{2}$-macroglobulin in the first peak of a Sephadex G-200 elution of ram serum and is presumably identical with it. As there was negligible selective concentration of serum proteins in our ultrafiltration procedure, $\alpha_{2}$-macroglobulin seems to be preferentially transferred to the tubule fluid. $\alpha_{2}$-Macroglobulin and its analogues have been implicated in the stimulation of DNA synthesis (Berenblum, Burger \& Knyszynski, 1968) and are present at elevated blood levels during periods of rapid cell division (Heim, 1968).

The concentrations of immunoglobulin in normal and concentrated rete testis fluid, ram serum and ram seminal plasma were determined by radial immunodiffusion, using anti-ram IgG or anti-ram light chain antisera produced in rabbits. A standard IgG was prepared by DEAE-cellulose ion exchange chromatography and calibrated by the Biuret reaction and by diffraction densitometry. Little immunoglobulin enters the seminiferous tubules, the concentration in rete testis fluid being about $0.2 \%$ of that in serum (Table 1 ). The immunoglobulin content of ram seminal plasma is about $2 \%$ of that of ram serum; this is a higher value than that for human seminal plasma where the IgG concentration is about $1 \%$ of that in serum and IgM and IgA levels are negligible (Johnson, unpublished observation).

These results show that the entry of appreciable amounts of serum protein from the interstitial tissue of the testis into the seminiferous tubules is prevented by a barrier which may also prevent or impede the entry of other proteins such as LH and FSH, as is suggested by some histological evidence (Mancini, Castro \& Sieguer, 1967). The presence of this barrier to protein must be of considerable importance in the immunological reaction in vivo against homologous spermatozoal antigen(s). Firstly, the barrier will presumably prevent spermatozoal antigens from leaking to the systemic circulation, and will thus reduce autoimmunization. Secondly, the complement-fixing IgG antibody cytotoxic to homologous spermatozoa which is present at low titre in the normal sera of several species (Edwards, 1960; Johnson, 1968) will not enter the tubules in sufficient quantity to lyse the contents. Thirdly, antibodies, induced by immunization with testis, will not be able to cause testicular damage unless the barrier to protein breaks down or unless the antibodies are of high titre, high avidity, or are transferred into the tubule lumen preferentially over other IgG molecules.

We would like to thank M. Hobart for the anti-sheep light chain antiserum and for performing the refraction densitometry, Miss V. Hunn for technical assistance and Dr R. G. Edwards for helpful discussion. This work was financed by the Medical Research Council (M.H.J.) a Royal Society and Nuffield Foundation Commonwealth Bursary (B.P.S.) and the Ford Foundation. 


\section{REFERENCES}

Berenglum, I., BURger, M. \& KNYszynexu, A. (1968) Regeneration of bone marrow cells and thymus induced by $19 \mathrm{~S} a_{2}$-globulin in irradiated mice. Nature, Lond. 217, 857.

Chutna, J. \& Rychlikova, M. (1964) A study of the biological effectiveness of antibodies in the development and prevention of experimental autoimmune aspermatogenesis. Folia biol., Praha, $10,188$.

Cowte, A. T., Lascelles, A. K. \& Wallace, J. C. (1964) The flow and protein content of testicular lymph in conscious rams. F. Physiol., Lond. 171, 176.

EDWARDs, R. G. (1960) Complement-fixing activity of normal rabbit serum with rabbit spermatozoa and seminal plasma. F. Reprod. Fert. 1, 268.

HEM, W. G. (1968) Relation between rat slow $a_{2}$ globulin and $a_{2}$-macroglobulin of other mammals. Nature, Lond. 217, 857.

Johnson, M. H. (1968) Characterization of a natural antibody in normal guinea-pig serum reacting with homologous spermatozoa. $\mathcal{F}$. Reprod. Fert. 16, 503.

Kormano, M. (1967) Distribution of injected L-3, 4-dihydroxyphenylalamine (L-dopa) in the adult rat testis and epididymis. Acta physiol. scand. 71, 125.

Mancini, R. E., Castro, A. \& SiegurR, A. G. (1967) Histologic localisation of follicle-stimulating and luteinising hormones in the rat testis. F. Histochem. Cytochem. 15, 516.

Mancini, R. E., Vilar, O., Alvarez, B. \& Sieguer, A. G. (1965) Extravascular and intratubular diffusion of labelled serum proteins in the rat testis. F. Histochem. Cytochem. 13, 376.

SETchell, B. P. (1967) The blood-testicular fluid barrier in sheep. F. Physiol., Lond. 189, 63p.

Voglmayr, J. K., Scott, T. W., Setchezl, B. P. \& Wartes, G. M. H. (1967). Metabolism of testicular spermatozoa and characteristics of testicular fluid collected from conscious rams. J. Reprod. Fert. $14,87$.

WADswORTH, C. \& HANSON, L. (1960) Comparative analysis of immune electrophoretic precipitates employing a modified immune electrophoretic technique. Int. Archs Allergy appl. Immun. 17, 165. 